\author{
Majed Sammak \\ Division of Thermal Power Engineering, \\ Department of Energy Sciences, \\ Lund University, \\ SE-221 00 Lund, Sweden \\ e-mail: majed.sammak@energy.lth.se
}

Egill Thorbergsson

e-mail: egill.thorbergsson@chalmers.se

\section{Tomas Grönstedt}

e-mail: tomas.gronstedt@chalmers.se

Division of Fluid Dynamics, Department of Applied Mechanics, Chalmers University, SE- 41296 Gothenburg, Sweden

\section{Magnus Genrup \\ Division of Thermal Power Engineering, Department of Energy Sciences, Lund University, \\ SE-221 00 Lund, Sweden e-mail: magnus.genrup@energy.Ith.se}

\section{Conceptual Mean-Line Design of Single and Twin-Shaft Oxy-Fuel Gas Turbine in a Semiclosed Oxy-Fuel Combustion Combined Cycle}

The aim of this study was to compare single-and twin-shaft oxy-fuel gas turbines in a semiclosed oxy-fuel combustion combined cycle (SCOC-CC). This paper discussed the turbomachinery preliminary mean-line design of oxy-fuel compressor and turbine. The conceptual turbine design was performed using the axial through-flow code LUAX-T, developed at Lund University. A tool for conceptual design of axial compressors developed at Chalmers University was used for the design of the compressor. The modeled SCOC-CC gave a net electrical efficiency of $46 \%$ and a net power of $106 \mathrm{MW}$. The production of $95 \%$ pure oxygen and the compression of $\mathrm{CO}_{2}$ reduced the gross efficiency of the SCOC$C C$ by 10 and 2 percentage points, respectively. The designed oxy-fuel gas turbine had a power of $86 \mathrm{MW}$. The rotational speed of the single-shaft gas turbine was set to $5200 \mathrm{rpm}$. The designed turbine had four stages, while the compressor had 18 stages. The turbine exit Mach number was calculated to be 0.6 and the calculated value of $A N^{2}$ was $40 \cdot 10^{6} \mathrm{rpm}^{2} \mathrm{~m}^{2}$. The total calculated cooling mass flow was $25 \%$ of the compressor mass flow, or $47 \mathrm{~kg} / \mathrm{s}$. The relative tip Mach number of the compressor at the first rotor stage was 1.15. The rotational speed of the twin-shaft gas generator was set to $7200 \mathrm{rpm}$, while that of the power turbine was set to $4800 \mathrm{rpm}$. A twin-shaft turbine was designed with five turbine stages to maintain the exit Mach number around 0.5. The twin-shaft turbine required a lower exit Mach number to maintain reasonable diffuser performance. The compressor turbine was designed with two stages while the power turbine had three stages. The study showed that a four-stage twin-shaft turbine produced a high exit Mach number. The calculated value of $A N^{2}$ was $38 \cdot 10^{6} \mathrm{rpm}^{2} \mathrm{~m}^{2}$. The total calculated cooling mass flow was $23 \%$ of the compressor mass flow, or $44 \mathrm{~kg} / \mathrm{s}$. The compressor was designed with 14 stages. The preliminary design parameters of the turbine and compressor were within established industrial ranges. From the results of this study, it was concluded that both single-and twin-shaft oxy-fuel gas turbines have advantages. The choice of a twin-shaft gas turbine can be motivated by the smaller compressor size and the advantage of greater flexibility in operation, mainly in the off-design mode. However, the advantages of a twin-shaft design must be weighed against the inherent simplicity and low cost of the simple single-shaft design. [DOI: 10.1115/1.4023886]

Keywords: SCOC-CC, oxy-fuel midsized combined cycle, $\mathrm{CO}_{2}$, single-shaft gas turbine, twin-shaft gas turbine

\section{Introduction}

The European Commission agreed on the "climate and energy package" in June 2009. The directives agreed upon in the package state that emissions should be cut by $20 \%$. Furthermore, a $20 \%$ improvement in energy efficiency and a $20 \%$ increase in renewable energy should be achieved by 2020 . The climate package comprises four main measures, including the revision and strengthening of the Emissions Trading System (ETS) as well as emission regulation in sectors not covered by the ETS, e.g. transport and housing. The measures further underline the importance of binding national targets for renewable energy and encouragement of the development and safe use of carbon capture and storage [1]. Several technologies are being considered for carbon dioxide separation; however, the most promising are post-

Contributed by the Combustion and Fuels Committee of ASME for publication in the Journal of Engineering for Gas Turbines and Power. Manuscript received December 21, 2012; final manuscript received February 11, 2013; published online June 24, 2013. Editor: David Wisler. combustion, precombustion, and oxy-fuel combustion [2]. These techniques have their advantages and disadvantages, and their commercialization will depend heavily on their technical and economic feasibility.

In the SCOC-CC the fuel is combusted with oxygen rather than air, and the exhaust gases consist mainly of water and $\mathrm{CO}_{2}$. The water is removed by condensation in the flue-gas condenser. The $\mathrm{CO}_{2}$-rich flue gas is then separated into two streams. The main stream is recirculated to the gas turbine, while the much smaller bleed stream is compressed prior to transport and storage. SCOC-CC offers the advantage of reducing $\mathrm{NO}_{\mathrm{x}}$ emissions since there is little nitrogen involved in the combustion process. However, separating oxygen in an air separation unit (ASU) is an energy-consuming process.

The SCOC-CC is being studied in the ENhanced CAPture of $\mathrm{CO}_{2}$ project, ENCAP [3] and the results published so far show that SCOC-CC has good feasibility. A comparative study of Graz cycle and SCOC-CC, in which a single-shaft oxy-fuel gas turbine was included, was published by Sanz et al. [4]. Furthermore, 
Woollatt and Franco [5] studied the turbomachinery design for both Graz cycle and SCOC-CC for nongeared $3000 \mathrm{rpm}$ designs, while Bolland et al. [6] compared different oxy-fuel cycles. Bolland and Mathieu [7] showed that the difference in power between dual- and triple-pressure steam cycles is very small. In a previous study, Sammak et al. [8] investigated a single-shaft oxy-fuel gas turbine with a rotational speed of $5200 \mathrm{rpm}$. Ulizar and Pilidis [9] studied twin-spool oxy-fuel gas turbines with a compressor turbine (CT) rotational speed of $5000 \mathrm{rpm}$ and a power turbine (PT) rotational speed of $3000 \mathrm{rpm}$. The objective of the present paper is to study the turbomachinery of the single- and twin-shaft oxy-fuel gas turbines. The study includes both mean-line design of the turbine and compressor. Depending on the shaft arrangement, industrial gas turbines can be classified as either single- or twin-shaft gas turbines. The single-shaft arrangement is better when a gas turbine is required to operate under fixed-load conditions. The turbine and the compressor are matched for a specific operation point, and single-shaft gas turbines are thus more suitable for base-load power generation. The turbine and compressor rotate at the same speed, and the shaft drives the generator directly or through a step-down gear box. Twin-shaft gas turbines are primarily used when flexibility of operation is of primary importance. The compressor turbine drives the compressor and they are together called a gas generator. The power turbine rotates at a lower speed than the gas generator and drives the generator directly or through a gear box. This configuration makes it possible to use a compressor with fewer stages. Twin-shaft gas turbines allow greater flexibility in gas turbine design as the gas generator and power turbine are connected to separate shafts.

\section{Method}

The thermodynamic simulations were performed using the commercial software IPSEPRO developed by SimTech Simulation Technology [10]. This program allows the implementation of user-defined fluid properties to simulate real gas properties of the working fluids. The physical properties of water and steam were calculated using the standard IAPWS-IF97 formulations in IPSEPRO [10]. IPSEPRO was linked to the NIST Reference Fluid Thermodynamic and Transport Properties Database (REFPROP). This helped in obtaining more realistic results, since REFPROP applied real gases physical properties [11]. The turbine mean-line design was carried out using the turbine design tool LUAX-T developed at Lund University. LUAX-T uses the refined Ainely and Mathieson mean-line loss model [12]. The model was modified by Moustapha et al. [13] and most recently by Benner et al. $[14,15]$. The loss model includes profile losses, trailing edge losses, secondary losses, and tip clearance losses. The code also uses fundamental equations for momentum, energy, and continuity to assess losses due to cooling, purging, and packing flows. The present version of LUAX-T allows three different methods of mixing coolant into the main stream, namely: (i) film, (ii) trailing-edge ejection, and (iii) packing and cavity purge flows. Losses due to coolant and packing flows are assessed by conservation of momentum and energy. The mixing routines result in a nonlinear system that must be solved iteratively for conservation of mass. Film losses are assessed through a generic free-stream velocity distribution and the Hartsel mixing method [16].

The compressor mean-line design was performed using a code developed at Chalmers University. This code uses empirical relations to estimate the losses. The empirical relations are implemented using the prediction model developed by Wright and Miller [17]. The prediction model estimates the profile and endwall losses, and the design code estimates the shock losses using a model developed by Schwenk et al. [18].

\section{Thermodynamic Evaluation of SCOC-CC}

The SCOC-CC can be decomposed into five main units: the gas turbine (Topping cycle), the heat recovery steam generator (HRSG) and steam turbine (Bottoming cycle), the flue-gas condenser, the ASU, and the $\mathrm{CO}_{2}$ compression train. A schematic overview of the SCOC-CC is presented in Fig. 1. Sanz et al. [4] has investigated larger SCOC-CC with a net power greater than $500 \mathrm{MW}$. This study is concerned with a midsized SCOC-CC with a net power output around $100 \mathrm{MW}$.

Topping Cycle. The fuel considered in this analysis is natural gas with a lower heating value of around $49 \mathrm{MJ} / \mathrm{kg}$. The fuel is combusted with oxygen under conditions close to stoichiometric. Oxygen of 95\% purity is produced in the ASU. The combustion products are thus mainly carbon dioxide and water, according to the combustion reaction

$$
\mathrm{CH}_{4}+2 \mathrm{O}_{2}=\mathrm{CO}_{2}+2 \mathrm{H}_{2} \mathrm{O}
$$

The water is subsequently removed by cooling in the flue-gas condenser, where the flue gas leaving the flue-gas condenser consists mainly of $\mathrm{CO}_{2}$ at a temperature around $20^{\circ} \mathrm{C}$ and a pressure close to atmospheric. The rich flue gas containing $\mathrm{CO}_{2}$ is then divided into two streams. Approximately $93 \%$ is recirculated back to the gas turbine, while the remaining rich flue gas is compressed and liquefied at a pressure of 200 bars to enable transport and storage in the dense phase. The compressor exit temperature is $388^{\circ} \mathrm{C}$ while the combustion outlet temperature is set to $1400^{\circ} \mathrm{C}$. The oxy-fuel gas turbine has a higher optimal pressure ratio than gas turbines with air as working fluid. The optimized SCOC-CC results in a pressure ratio of 37 . This high pressure ratio results in an exhaust gas temperature of about $620^{\circ} \mathrm{C}$, which is optimal for the steam cycle.

Bottoming Cycle. The bottoming steam cycle was designed to obtain the maximal thermal efficiency from the gas turbine exhaust gases. The optimized HRSG employs two pressure levels. The HRSG includes a low-pressure economizer, evaporator, and superheater, a high-pressure economizer, evaporator, and superheater, and low-pressure reheater. The inlet pressure and steam turbine temperature are set so as to maintain the moisture content within acceptable limits at the end of the steam turbine to avoid the risk of erosion. The inlet steam is set to a temperature of $565^{\circ} \mathrm{C}$ and a pressure of 127 bars. The static pressure of the condenser is set to 0.045 bars, assuming a cooling water temperature of $15^{\circ} \mathrm{C}$.

The performance of the steam turbine has been assessed in detail using the Siemens in-house design code for steam turbines. However, due to the proprietary nature of this information no details can be given here. Heated steam from the low-pressure evaporator feeds into the lower part of the deaerator and heats the water to the saturation temperature, releasing incondensable gases. The deaerator operates at $105^{\circ} \mathrm{C}$ and the outgoing water is cooled by the incoming condensate to approximately $60^{\circ} \mathrm{C}$. This is limited by the requirement of a temperature difference of $13{ }^{\circ} \mathrm{C}$ for efficient deaeration. The flue-gas exit temperature from the HRSG of $69^{\circ} \mathrm{C}$ is lower than in the regular dual-pressure combined cycle. This is due to the fact that the specific heat of the flue gas is lower than in conventional cycles. The ASU was chosen to produce a high quantity of oxygen. The economic production of large amount of oxygen can be achieved with cryogenic air separation $[7,19]$. The power required to obtain oxygen of $95 \%$ purity was assumed to be $900 \mathrm{~kJ} / \mathrm{kg} \mathrm{O}_{2}$ and that for compression $325 \mathrm{~kJ} / \mathrm{kg} \mathrm{O}_{2}$ [4]. The energy required for $\mathrm{CO}_{2}$ compression was assumed to be $350 \mathrm{~kJ} / \mathrm{kg} \mathrm{CO} 2$ [4]. According to Darde et al. [20] and Amann et al. [21], ASU energy consumption increases drastically above an oxygen purity of $95 \%$.

The ASU stream consists of 95 wt. $\% \mathrm{O}_{2}, 3$ wt. $\%$ Ar and 2 wt. $\%$ $\mathrm{N}_{2}$. The natural gas combusted with oxygen consists primary of 77 wt. $\% \mathrm{CH}_{4}, 10$ wt. $\% \mathrm{C}_{2} \mathrm{H}_{6}, 10$ wt. $\% \mathrm{C}_{3} \mathrm{H}_{8}$, and a small percent of $\mathrm{N}_{2}$ and $\mathrm{CO}_{2}$. The working fluid through the cycle is presented in Table 1 while the performance of the SCOC-CC is presented in Table 2. It should be clear that the cycle study in the paper is 


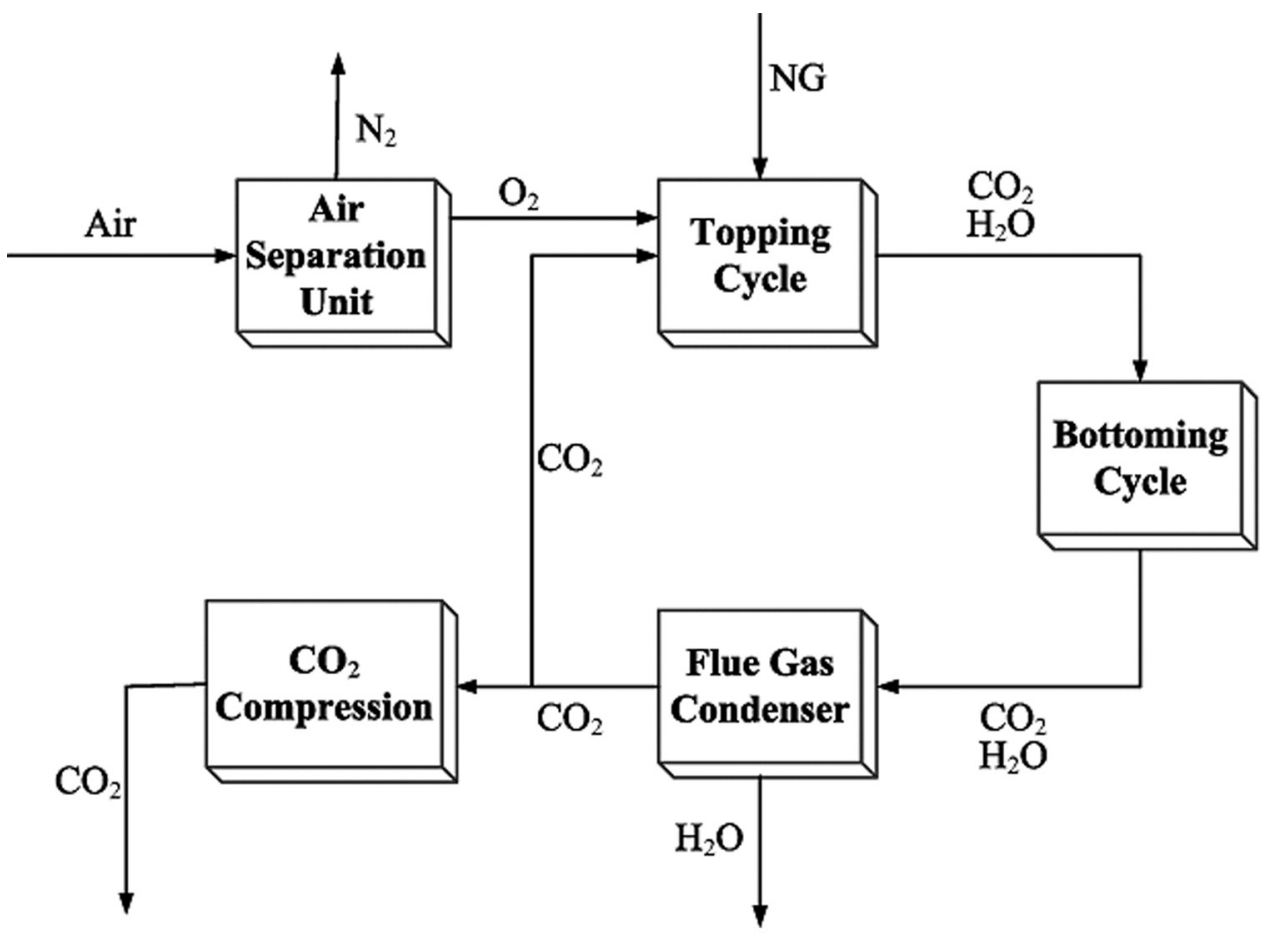

(a)

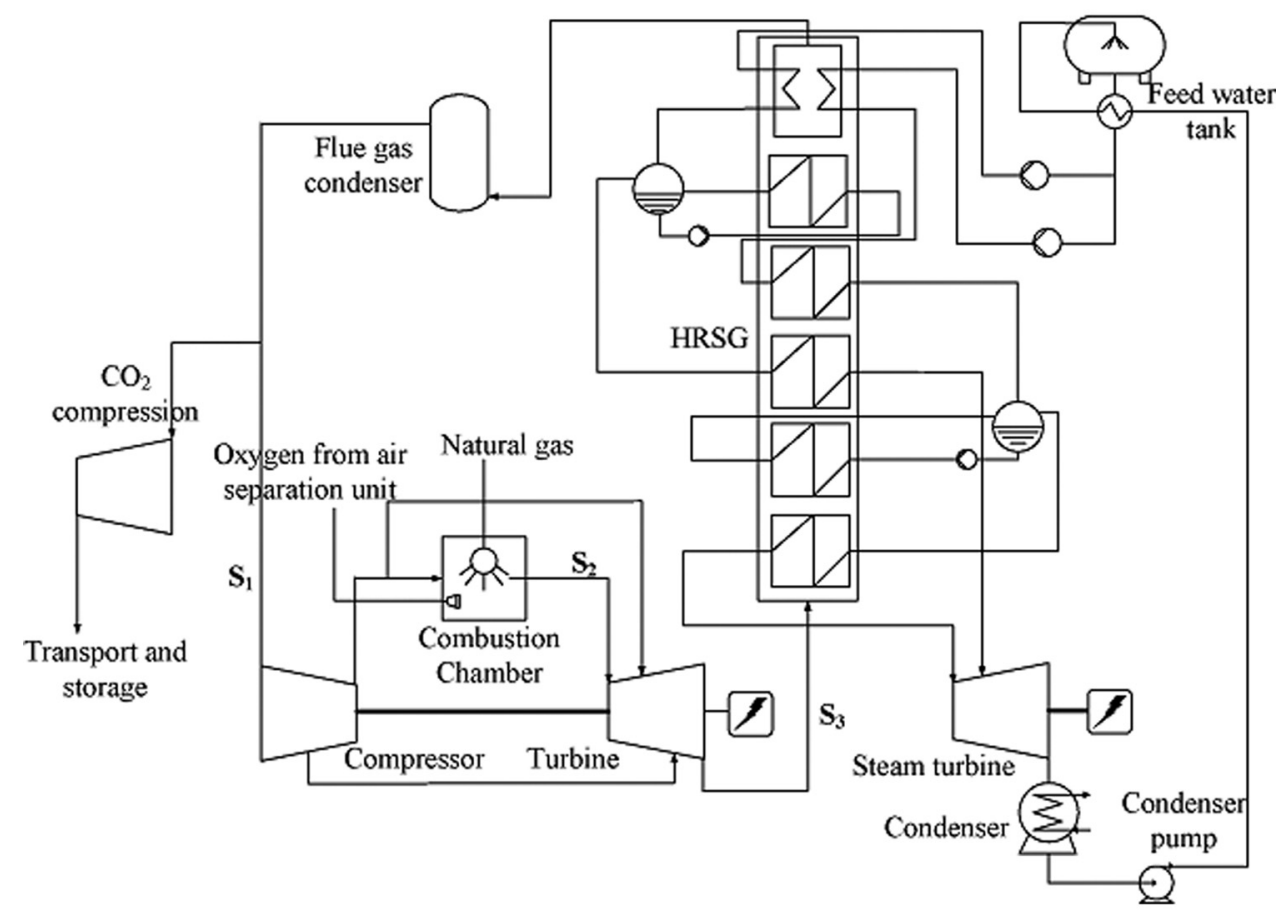

(b)

Fig. 1 Principle flow scheme of SCOC-CC

limited to the design point. The parametric analysis and off design performance studies are not covered in this paper.

The calculated net power was $106 \mathrm{MW}$, while the net efficiency was $46 \%$. The simulated SCOC-CC showed a calculated gas turbine power of $86 \mathrm{MW}$. The major drawback of the SCOC-CC is the energy required by the $\mathrm{ASU}$, which reduces the gross efficiency by $10 \%$. Further ASU optimization and full integration with oxy-fuel cycles is therefore necessary. The loss in gross efficiency due to $\mathrm{CO}_{2}$ compression was calculated to be $2 \%$.

\section{Turbomachinery Design}

Oxy-fuel combustion takes place with existence of oxygen instead of air, resulting in flue gas that is mainly $\mathrm{CO}_{2}$ and $\mathrm{H}_{2} \mathrm{O}$. Thus, due to changing working fluid, the oxy-fuel turbomachinery must be redesigned.

Compressor Design. To obtain guidance in choosing the rotational speed for an oxy-fuel gas turbine, nondimensional groups 
Table 1 SCOC-CC working fluid

\begin{tabular}{llccc}
\hline \hline Stream & & $\mathrm{S}_{1}$ & $\mathrm{~S}_{2}$ & $\mathrm{~S}_{3}$ \\
\hline $\mathrm{CO}_{2}$ & wt. \% & 92 & 86.5 & 87.7 \\
$\mathrm{~N}_{2}$ & wt. \% & 2.85 & 2.7 & 2.7 \\
$\mathrm{Ar}$ & wt. \% & 4.06 & 3.8 & 3.9 \\
$\mathrm{H}_{2} \mathrm{O}$ & w. \% & 0.97 & 6.8 & 5.5 \\
$\mathrm{O}_{2}$ & wt. \% & 0.11 & 0.11 & 0.11 \\
\hline \hline
\end{tabular}

Table 2 SCOC-CC power performance

\begin{tabular}{lcr}
\hline \hline & Unit & Value \\
\hline Compressor mass flow & $\mathrm{kg} / \mathrm{s}$ & 190 \\
Compressor pressure ratio & - & 37 \\
Combustor outlet temp. & ${ }^{\circ} \mathrm{C}$ & 1400 \\
Gas turbine power & $\mathrm{MW}$ & 86 \\
Gas turbine power, compressor & $\mathrm{MW}$ & 67 \\
Gas turbine power, turbine & $\mathrm{MW}$ & 155 \\
Total heat input & $\mathrm{MW}$ & 230 \\
Steam turbine power & $\mathrm{MW}$ & 48 \\
Pumps power & $\mathrm{MW}$ & 0.5 \\
Gross power output & $\mathrm{MW}$ & 134 \\
Gross efficiency & $\%$ & 58 \\
$\mathrm{O}_{2}$ generation + compression & $\mathrm{MW}$ & 23 \\
$\mathrm{CO} 2$ compression to 200 bar & $\mathrm{MW}$ & 5 \\
Net power output & $\mathrm{MW}$ & 106 \\
Net efficiency & $\%$ & 46 \\
\hline
\end{tabular}

were used. These groups contain all variables describing gas turbine performance, including fluid properties [22]. From the definitions of nondimensional mass flow (Eq. (2)) and rotational speed (Eq. (3)), Eq. (4) can be written, which describes the relation between nondimensional mass flow for air and $\mathrm{CO}_{2}$.

$$
\begin{gathered}
\text { Dimensionless mass flow }=\frac{\dot{\mathrm{m}} \cdot \sqrt{\mathrm{T} \cdot \mathrm{R}}}{\mathrm{D}^{2} \cdot \mathrm{p} \cdot \sqrt{\gamma}} \\
\text { Rotational speed } \mathrm{N}=\frac{\mathrm{U} \cdot 60}{\pi \cdot \mathrm{D}} \\
\frac{\dot{\mathrm{m}}_{\mathrm{AIR}}}{\dot{\mathrm{m}}_{\mathrm{CO} 2}}=\frac{\mathrm{N}_{\mathrm{CO} 2}^{2}}{\mathrm{~N}_{\mathrm{AIR}}^{2}}\left(\frac{\sqrt{\mathrm{R}_{\mathrm{CO} 2} \cdot \gamma_{\mathrm{Air}}}}{\sqrt{\mathrm{R}_{\mathrm{Air}} \cdot \gamma_{\mathrm{CO} 2}}}\right)
\end{gathered}
$$

Equation (4) takes into account the fluid properties and can thus be used in scaling the oxy-fuel compressor based on an existing conventional air compressor. This choice of rotational speed should fulfill the turbine design requirements and ensure that the turbine $\mathrm{AN}^{2}$ is kept within acceptable limits. $\mathrm{AN}^{2}$ is defined as the annulus area of rotor blade times rotational speed square and $\mathrm{AN}^{2}$ is proportional to the blade root stress [23]. The maximal relative tip Mach number occurs at the first rotor of the compressor. Higher Mach numbers can be tolerated in advanced design methods; however, these methods are costly and it is therefore advantageous to keep the tip Mach number as low as possible. To ensure stable flow into the combustion chamber the compressor exit Mach number must be kept below 0.4. Equation (5) combines the Euler equation of turbomachinery and the diffusion factor (DF) [24].

$$
\Delta \mathrm{h}_{0}=2 \sigma \mathrm{UW}_{1}\left(\mathrm{DF}-1+\frac{\mathrm{W}_{2}}{\mathrm{~W}_{1}}\right)
$$

The above equation shows that work per stage is proportional to blade speed and solidity $\left(\sigma=\frac{\mathrm{s}}{\mathrm{s}}\right)$. Increasing the compressor stage loading reduces the number of stages required to achieve a specific pressure ratio and thus reduces the size of the compressor. However, high stage loading reduces compressor efficiency and the stall margin, and the compressor design is thus a compromise between these requirements. High levels of diffusion produce thick boundary layers along the compressor blade surfaces, causing flow separation to occur. The diffusion factor should preferably be kept under 0.6 in order to maintain compressor performance. The endwall losses are also highly dependent on the diffusion factor. For high values of solidity, the diffusion factor must be reduced in order to maintain low endwall losses. The compressor flow coefficient is usually maintained between 0.5 and 0.75 [25].

Turbine Design. Carbon dioxide has a lower ratio of specific heat and a higher density than air. The speed of sound in a denser gas is lower, and the exit Mach number of the oxy-fuel turbine is thus higher than for turbines using air as the working fluid. Several parameters must be considered in the design of a suitable turbine. The choice of rotational speed took into account the aerodynamic requirements balancing between the exit Mach number, as well as the last stage loading coefficient and the avoidance of high $\mathrm{AN}^{2}$. The maximum allowed value of $\mathrm{AN}^{2}$ to maintain mechanical integrity is $50 \cdot 10^{6} \mathrm{rpm}^{2} \mathrm{~m}^{2}$, and thus the rim speed is limited into $400 \mathrm{~m} / \mathrm{s}$ [22]. The inlet Mach number should be kept below 0.2 in order to minimize pressure losses. The stage loading in the last stage of the turbine should preferentially have a low value to ensure low axial velocity at the turbine exit and hence maintain good diffusor performance. The last stage loading is kept between 1 and 1.2 [22]. It is recommended that the turbine exit swirl angle be maintained between $-5 \mathrm{deg}$ and $-10 \mathrm{deg}$, to limit the pressure losses in the diffuser. Designing a good diffuser is of the utmost importance in order to avoid flow separation from the endwalls influencing gas turbine efficiency. The turbine exit Mach number should preferably be in the range of 0.5-0.6. Single-shaft gas turbines have a cold end drive. The shaft connected to the generator from the compressor side enables the mounting of a long conical diffuser with a high pressure recovery coefficient of around 0.8 . The twin-shaft gas turbine arrangement has a hot end drive. The power turbine shaft is connected to the generator directly or through a gearbox, while the short conical diffuser is attached to a collector box. The twin-shaft turbine has a pressure recovery coefficient of around 0.65 . The single-shaft gas turbine diffuser is more efficient than the twin-shaft gas turbine diffuser allowing a higher exit Mach number.

The first turbine stage has virtually no inner wall hade, while the next one has a hade of about $8 \mathrm{deg}$. The first two rotors are cylindrical to satisfy minimum running clearance requirements. In order to avoid flow separation, the outer wall hade was set to a maximum of $25 \mathrm{deg}$ to maintain a maximum opening of approximately $35 \mathrm{deg}$ [22]. The axial gap between the stator and rotor blades should be kept within approximately $25 \%$ of the blade axial chord in order to avoid blade vibration. In the case of the twin-shaft turbine, the interturbine duct has a conical shape to control diffusion and avoid flow separation. The equivalent conical divergence angle should not exceed $25 \mathrm{deg}$, while the area ratio of the diffuser should be less than 1.3 [13]. Figure 2 shows the Sovran and Klomp chart for the performance of a conical diffuser

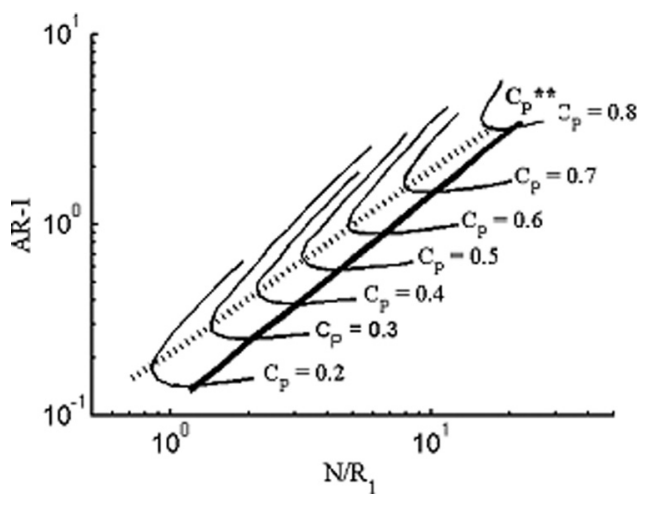

Fig. 2 Sovran and Klomp chart 


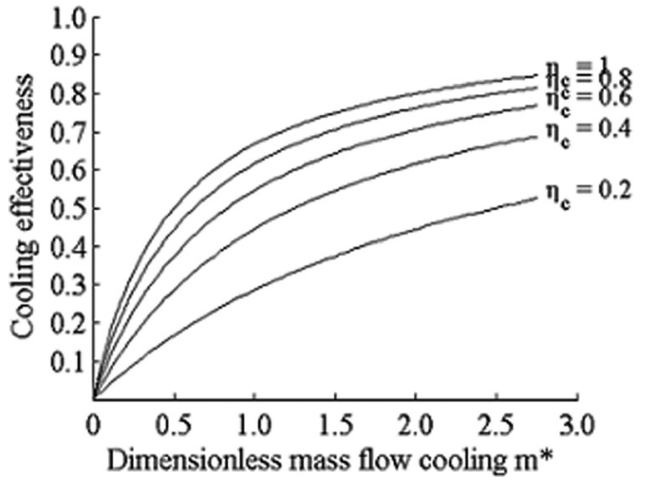

Fig. 3 Cooling effectiveness as function of dimensionless mass flow

[25]. The diffuser nondimensional length $\left(\mathrm{N} / \mathrm{R}_{1}\right)$ producing maximum pressure recovery $\left(\mathrm{Cp}^{* *}\right)$ at the area ratio of 1.3 is 2.46 . The axial aspect ratio (height/axial chord) should preferentially be kept between the values 1.1 and 1.3. Low aspect ratios increase secondary losses, while high aspect ratios increase the $\mathrm{AN}^{2}$.

In SCOC-CC, the combustion outlet temperature was higher due to changing gas turbine working fluid and was set to $1400^{\circ} \mathrm{C}$. This firing level exceeds the blade material limitations. The study assumed using high temperature material such as fourth generation single crystal alloys in manufacturing turbine blades [26,27]. Thus the stator metal temperature was set to $950{ }^{\circ} \mathrm{C}$, while the rotor metal temperature was set to $920^{\circ} \mathrm{C}$. The metal temperature is a function of the material properties and cooling technique. It is thus important that the metal temperature does not exceed the permissible limits in order to ensure adequate blade life. The cooling effectiveness $(\varepsilon)$ describes the cooling duty and is a measure of the amount of cooling required to maintain a particular metal temperature. Figure 3 shows the correlation between cooling effectiveness, cooling efficiency, and dimensionless mass flow [13]. Convection and film cooling are present in the first stage and the cooling efficiency was thus set to 0.8 . Later cooled stages use convection cooling and the stator cooling efficiency was therefore set to 0.5 , while the rotor cooling efficiency was set to 0.4 . The cooling mass flow was estimated using the standard m-star model $[13,28,29]$, as described by the following equations.

$$
\begin{aligned}
\varepsilon & =\frac{\mathrm{T}_{\text {gas }}-\mathrm{T}_{\text {metal }}}{\mathrm{T}_{\text {gas }}-\mathrm{T}_{\text {cool }}} \\
\varepsilon & =\frac{\mathrm{m}^{*} \eta_{\text {cool }}}{1+\mathrm{m}^{*} \eta_{\text {cool }}} \\
\mathrm{m}^{*} & =\frac{\dot{\mathrm{m}}_{\mathrm{cool}} \cdot \mathrm{c}_{\mathrm{p} . \text { cool }}}{\mathrm{HTC} \cdot 2.2 \cdot \mathrm{C} \cdot \mathrm{h}}
\end{aligned}
$$

The temperature profile of the main gas is not homogeneous over the radius of the blade, necessitating adjustment of the inlet gas

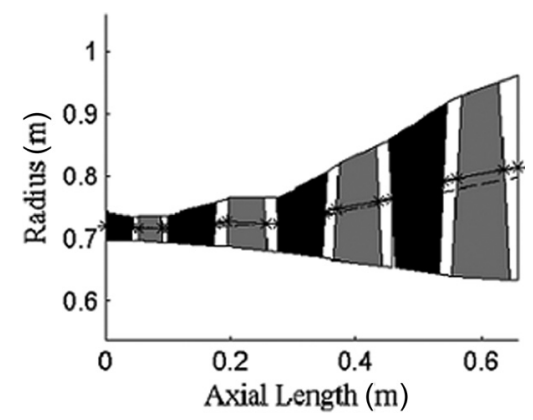

Fig. 4 Annulus of the conceptual design of the single-shaft SCOC-CC turbine
Table 3 Single-shaft SCOC-CC turbine design data

\begin{tabular}{lllll}
\hline \hline & Stage 1 & Stage 2 & Stage 3 & Stage 4 \\
\hline$\psi=\Delta \mathrm{h}_{0} / \mathrm{U}^{2}$ & 1.5 & 1.3 & 1.1 & 1.0 \\
$\varphi=\mathrm{C}_{\mathrm{m}} / \mathrm{U}$ & 0.37 & 0.4 & 0.39 & 0.4 \\
$\mathrm{PR}$ & 2.3 & 2.3 & 2.2 & 3 \\
$\Lambda_{p}$ & 0.30 & 0.38 & 0.38 & 0.40 \\
$\varepsilon_{\text {str }} / \varepsilon_{\mathrm{rtr}}$ & $0.46 / 0.40$ & $0.32 / 0.21$ & - & - \\
\hline \hline
\end{tabular}

temperature. This is achieved by introducing the overall temperature distribution factor (OTDF) and the radial temperature distribution factor (RTDF). The OTDF was set to 0.05 while the RTDF was set to 0.025 [22]. This is the case in the front stages; however, this effect decreases in the rear stages due to spanwise mixing.

\section{Results}

The oxy-fuel gas turbine had a power of $86 \mathrm{MW}$. The availability of gearboxes with power exceeding $100 \mathrm{MW}$ makes it possible to design gas turbines with higher rotational speed and fewer stages.

Single-Shaft Oxy-Fuel Gas Turbine. The rotational speed was set into $5200 \mathrm{rpm}$ and thus a reduction gearbox is needed to drive the generator. The inlet Mach number was 0.12. The calculated $\mathrm{AN}^{2}$ was $40 \cdot 10^{6} \mathrm{rpm}^{2} \mathrm{~m}^{2}$ and the rim speed was set to $380 \mathrm{~m} / \mathrm{s}$. The designed single-shaft turbine had four stages. The turbine exit swirl angle was $-4 \mathrm{deg}$, which is acceptable. The annulus of the turbine is shown in Fig. 4, while the flow coefficients, stage loading coefficients, and the degree of reactions are presented in Table 3. The exit Mach number from the last turbine stage was 0.6 , which is within acceptable limits. The first two stages were the cooling stages and the total cooling flow was $47 \mathrm{~kg} / \mathrm{s}$, which corresponds to $25 \%$ of the compressor mass flow.

The compressor was designed to maintain a relative tip Mach number of 1.15 at the first rotor, while the inlet swirl angle at the tip was set to $20 \mathrm{deg}$. The Mach number at the compressor inlet was set to 0.6 . The compressor exit hub-to-tip ratio was designed so it does not exceed the maximum allowable limit 0.92 , while maintaining the pressure ratio. The compressor was designed to have a constant hub radius after the first two stages. The compressor had 18 stages to achieve a pressure ratio of 37 . The Mach number at the compressor exit was around 0.32 . The annulus of the compressor is shown in Fig. 5 and data regarding compressor design are presented in Table 4.

The feasibility and number of stages of the single-shaft oxyfuel compressor are quite sensitive to the compressor exit hub tip ratio. Thus, in order to reduce compressor size, the rotational speed must be increased. It should be noted that the rotational speed is constrained by the maximal permissible $\mathrm{AN}^{2}$.

Twin-Shaft Oxy-Fuel Gas Turbine. The twin-shaft gas turbine consists of a gas generator and a power turbine. The

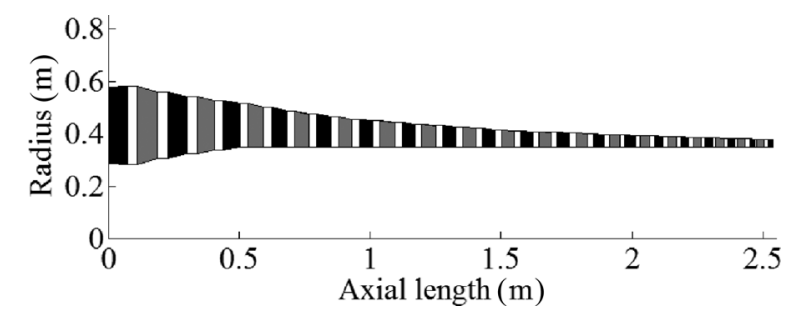

Fig. 5 Annulus of the conceptual design of the single-shaft SCOC-CC compressor 
Table 4 Single-shaft SCOC-CC compressor design data

\begin{tabular}{lcccc}
\hline \hline & Stage 1 & Stage 2 & Stage 6 & Stage 10 \\
\hline $\mathrm{C}_{\mathrm{ax}}$ & 160 & 157 & 145 & 134 \\
$\phi_{\mathrm{m}}$ & 0.68 & 0.67 & 0.67 & 0.65 \\
$\psi_{\mathrm{m}}$ & 0.46 & 0.46 & 0.45 & 0.45 \\
$\mathrm{PR}$ & 1.48 & 1.43 & 1.25 & 1.18 \\
$\left(\mathrm{r}_{\text {hub }} / \mathrm{r}_{\text {tip }}\right)_{\text {exit }}$ & 0.59 & 0.68 & 0.80 & 0.87 \\
& Stage 12 & Stage 14 & Stage 16 & Stage 18 \\
\hline $\mathrm{C}_{\mathrm{ax}}$ & 128 & 123 & 119 & 114 \\
$\varphi_{\mathrm{m}}$ & 0.63 & 0.61 & 0.60 & 0.58 \\
$\psi_{\mathrm{m}}$ & 0.45 & 0.45 & 0.45 & 0.45 \\
$\mathrm{PR}$ & 1.16 & 1.15 & 1.14 & 1.12 \\
$\left(\mathrm{r}_{\text {hub }} / \mathrm{r}_{\text {tip }}\right)_{\text {exit }}$ & 0.89 & 0.90 & 0.92 & 0.92 \\
\hline \hline
\end{tabular}

compressor turbine drives the compressor and runs at the same speed. The power turbine runs at a lower rotational speed than the gas generator, and is connected to the generator through the gearbox. The gas generator rotational speed was set to $7200 \mathrm{rpm}$ while shaft turbine was designed to have two compressor turbine stages and three power turbine stages. The inlet Mach number was 0.12 and turbine exit swirl angle was $-6 \mathrm{deg}$. The Mach number at the exit of the last stage of the power turbine was 0.5 , which is suitable for a hot end drive. The $\mathrm{AN}^{2}$ was $38 \cdot 10^{6} \mathrm{rpm}^{2} \mathrm{~m}^{2}$. The annulus area of the twin-shaft turbine is presented in Fig. 6. The design parameters for a twin-shaft oxy-fuel turbine are presented in Table 5. Designing the twin-shaft oxy-fuel turbine with two power turbine stages resulted in a high exit Mach number and high stage loading. Furthermore, increasing the power turbine rotational speed in order to reduce the exit Mach number increased the $\mathrm{AN}^{2}$ above permissible limits and thus this design is considered not suitable. Reducing the power turbine rotational speed to $3000 \mathrm{rpm}$ in order to allow the power turbine shaft to be connected directly to the generator resulted in two additional power turbine stages. The cooling mass flow was determined to be $44 \mathrm{~kg} / \mathrm{s}$, which represents $23 \%$ of the compressor mass flow.

Increasing the rotational speed from $5200 \mathrm{rpm}$ to $7200 \mathrm{rpm}$ increased the compressor first rotor relative tip Mach number from 1.15 to 1.35 , and consequently the inlet radius decreased. The mean radius Mach number is subsonic and thus no shock losses were present. The compressor inlet swirl angle was set into $25 \mathrm{deg}$. In order to achieve an overall pressure of 37 bars, the compressor was designed to have 14 stages. The exit Mach number was 0.36. The annulus of the compressor is shown in Fig. 7 and the design data for the compressor are given in Table 6.

According to Jonsson and Bolland [30] the cooling mass fraction is lower in oxy-fuel turbines than in air-cooled gas turbines. However, Corchero et al. [31] reported that the cooling mass flow the power turbine rotational speed was set to $4800 \mathrm{rpm}$. The twin-

Table 5 Twin-shaft SCOC-CC turbine design data

\begin{tabular}{llllll}
\hline \hline \multicolumn{5}{c}{$\mathrm{CT}$} & \multicolumn{5}{c}{$\mathrm{PT}$} \\
\hline & Stage 1 & Stage 2 & Stage 3 & Stage 4 & Stage 5 \\
$\psi=\Delta \mathrm{h}_{0} / \mathrm{U}^{2}$ & 1.2 & 1.2 & 1.3 & 1.3 & 1.1 \\
$\phi=\mathrm{C}_{\mathrm{m}} / \mathrm{U}$ & 0.44 & 0.44 & 0.7 & 0.5 & 0.55 \\
$\mathrm{PR}$ & 2 & 2 & 1.8 & 2 & 2.3 \\
$\Lambda_{p}$ & 0.30 & 0.38 & 0.38 & 0.40 & 0.4 \\
$\varepsilon_{\mathrm{str}} / \varepsilon_{\mathrm{rtr}}$ & $0.46 / 0.39$ & $0.32 / 0.21$ & $0.10 /-$ & - & - \\
\hline \hline
\end{tabular}

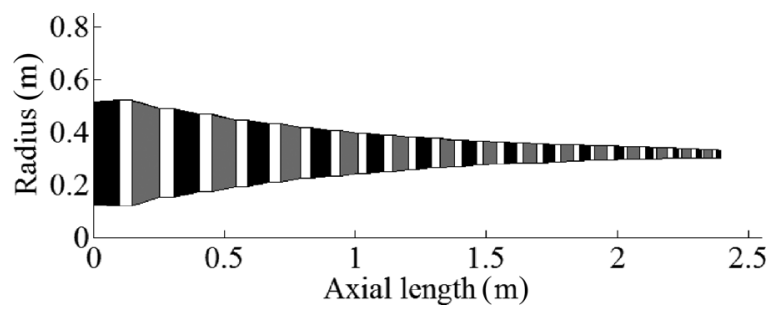

Fig. 7 Annulus of the conceptual design of the twin-shaft SCOC-CC compressor

fraction was similar in $\mathrm{CO}_{2}$ - and air-cooled gas turbines. This paper showed that the cooling effectiveness of the first stage stator for single- and twin-shaft turbines was around $46 \%$. The cooling effectiveness for air-cooled turbines is however higher and is around $55 \%$. Equation ( $6 a$ ) states that cooling effectiveness is a function of flow gas temperature, blade metal temperature and coolant temperature. A low cooling effectiveness indicates that the blade metal temperature is close to the gas temperature, which results in a lower requirement of cooling mass flow. Cooling effectiveness is lower in oxy-fuel turbines than air-cooled turbines, and oxy-fuel turbines thus require less cooling mass flow. Moreover, oxy-fuel turbines operate at higher gas temperatures and lower coolant temperatures than air-cooled turbines. The coolant temperature was determined to be $388^{\circ} \mathrm{C}$ in the modeled SCOC-CC while it is approximately $550^{\circ} \mathrm{C}$ in air-cooled gas turbines. Furthermore, Eqs. $(6 b)$ and $(6 c)$ illustrates that dimensionless cooling mass flow is a function of cooling effectiveness, heat transfer coefficient, and cooling area. This paper showed a cooled power turbine first stage stator that is not present in air-cooled turbines. The total cooling area in oxy-fuel turbines is thus larger. Consequently, the cooling requirements in oxy-fuel gas turbines and air-cooled turbines can be compared by estimating the cooling mass flow divided by the total cooled area. Further studies have to be performed before drawing conclusions.

Table 6 Twin-shaft SCOC-CC compressor design data

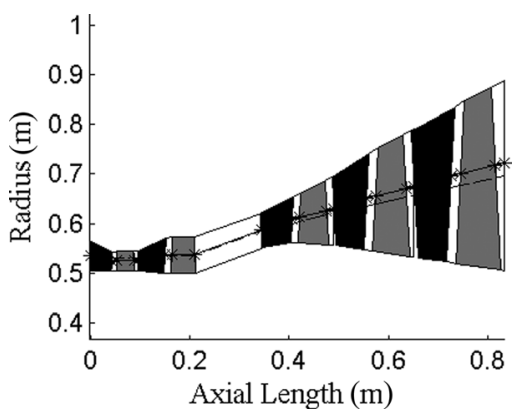

Fig. 6 Annulus of the conceptual design of the twin-shaft SCOC-CC turbine

\begin{tabular}{lcccc}
\hline & Stage 1 & Stage 3 & Stage 5 & Stage 7 \\
\hline $\mathrm{C}_{\mathrm{ax}}$ & 160 & 154 & 148 & 142 \\
$\varphi_{\mathrm{m}}$ & 0.66 & 0.64 & 0.61 & 0.59 \\
$\psi_{\mathrm{m}}$ & 0.45 & 0.45 & 0.45 & 0.45 \\
$\mathrm{PR}$ & 1.50 & 1.40 & 1.33 & 1.28 \\
$\left(\mathrm{r}_{\text {hub }} / \mathrm{r}_{\text {tip }}\right)_{\text {exit }}$ & 0.37 & 0.57 & 0.70 & 0.78 \\
& Stage 9 & Stage 11 & Stage 13 & Stage 14 \\
& 136 & 131 & 126 & 123 \\
$\mathrm{C}_{\mathrm{ax}}$ & 0.57 & 0.54 & 0.52 & 0.52 \\
$\varphi_{\mathrm{m}}$ & 0.45 & 0.45 & 0.41 & 0.40 \\
$\psi_{\mathrm{m}}$ & 1.25 & 1.22 & 1.18 & 1.17 \\
$\mathrm{PR}$ & 0.84 & 0.87 & 0.90 & 0.91 \\
$\left(\mathrm{r}_{\text {hub }} / \mathrm{r}_{\text {tip }}\right)_{\text {exit }}$ & & & & \\
\hline \hline
\end{tabular}




\section{Conclusions}

The aim of this study was to compare single- and twin-shaft oxyfuel gas turbines in a semiclosed oxy-fuel combustion combined cycle (SCOC-CC). The designed SCOC-CC had a net power output of $106 \mathrm{MW}$ and a net efficiency of $46 \%$. The oxygen required for oxy-fuel combustion was produced at $95 \%$, which reduced the gross efficiency by 10 percentage points. The compression of $\mathrm{CO}_{2}$ reduced the gross efficiency by an additional two percentage points. The designed oxy-fuel gas turbine had a power of $86 \mathrm{MW}$. The single-shaft gas turbine rotational speed was set to $5200 \mathrm{rpm}$. The designed turbine had four stages, and the exit Mach number was 0.60 . The total calculated cooling flow was $25 \%$ of the compressor mass flow, or $47 \mathrm{~kg} / \mathrm{s}$. The compressor was designed to have 18 stages, and the relative tip Mach number at the first stage was 1.15. The calculated value of the $\mathrm{AN}^{2}$ was found to be $40 \cdot 10^{6} \mathrm{rpm}^{2} \mathrm{~m}^{2}$. The rotational speed of the twin-shaft gas generator was set to $7200 \mathrm{rpm}$ and that of the power turbine to $4800 \mathrm{rpm}$. In order to maintain a low exit Mach number from the turbine, a five-stage turbine was suggested. The calculated cooling mass flow was $23 \%$ of the compressor mass flow, or $44 \mathrm{~kg} / \mathrm{s}$. From the evaluation of the twin-shaft turbine, it was concluded that a four stages turbine led to a high stage loading and high exit Mach number. The compressor turbine was designed with two stages and the power pressure turbine designed with three stages. The calculated exit Mach number was 0.5 , which is favorable for hot end drive turbines. The higher rotational speed of the compressor allowed for designing the compressor with fewer stages. The compressor was thus designed with 14 stages. In general, the design parameters were kept within acceptable limits. A twin-shaft oxy-fuel gas turbine offers more flexibility in operation and shorter start-up times. Allowing a higher rotational speed in the compressor led to fewer stages being needed, reducing the compressor size. However, the advantages of a twinshaft design must always be weighed against the inherent simplicity and lower cost of the simple single-shaft design.

\section{Nomenclature}

$$
\begin{aligned}
\mathrm{A} & =\text { area }\left(\mathrm{m}^{2}\right) \\
\mathrm{AR} & =\text { area ratio } \\
\mathrm{ASU} & =\text { air Separation Unit } \\
\mathrm{C} & =\text { blade chord }(\mathrm{m}) \\
\mathrm{C}_{\mathrm{m}} & =\text { meridional velocity }(\mathrm{m} / \mathrm{s}) \\
\mathrm{C} & =\text { specific heat capacity }(\mathrm{kJ} / \mathrm{kg} \cdot \mathrm{K}) \\
\mathrm{Cp} & =\text { pressure recovery coefficient } \\
\mathrm{CT} & =\text { compressor turbine } \\
\mathrm{DF} & =\text { diffusion factor } \\
\mathrm{D} & =\text { diameter }(\mathrm{m}) \\
\mathrm{h} & =\text { height }(\mathrm{m}) \\
\mathrm{HRSG} & =\text { heat recovery steam generator } \\
\mathrm{HTC} & =\text { heat transfer coefficient }\left(\mathrm{W} / \mathrm{m}^{2} \cdot \mathrm{K}\right) \\
\mathrm{m} & =\text { mass flow }(\mathrm{kg} / \mathrm{s}) \\
\mathrm{m}^{*} & =\text { dimensionless mass flow } \\
\mathrm{N} & =\text { rotational speed }(\mathrm{rpm}) \\
\mathrm{OTDF} & =\text { overall temperature distribution factor } \\
\mathrm{p} & =\text { pressure }(\text { bars }) \\
\mathrm{PR} & =\text { pressure ratio } \\
\mathrm{PT} & =\text { power turbine } \\
\mathrm{r} & =\text { radius }(\mathrm{m}) \\
\mathrm{R} & =\text { gas constant }\left(\mathrm{kJ} / \mathrm{kg}{ }^{\circ} \mathrm{C}\right) \\
\mathrm{RTDF} & =\text { radial temperature distribution factor } \\
\mathrm{S} & =\text { spacing }(\mathrm{m}) \\
\mathrm{SCOC}-\mathrm{CC} & =\text { semiclosed oxy-fuel combustion combined cycle } \\
\mathrm{T} & =\text { temperature }\left({ }^{\circ} \mathrm{C} \text { or } \mathrm{K}\right) \\
\mathrm{U} & =\text { blade speed }(\mathrm{m} / \mathrm{s}) \\
\mathrm{W} & =\text { relative velocity }(\mathrm{m} / \mathrm{s}) \\
&
\end{aligned}
$$

\section{Greek Symbols}

$$
\begin{aligned}
\gamma & =\text { ratio of specific heat } \\
\Delta \mathrm{h}_{0} & =\text { stage work }
\end{aligned}
$$

$\varepsilon=$ cooling effectiveness

$\eta=\operatorname{efficiency}(\%)$

$\Lambda_{p}=$ reaction degree based on pressure

$\sigma=$ solidity

$\varphi=$ flow coefficient

$\psi=$ blade loading coefficient

\section{Subscripts}

$\mathrm{ax}=$ axial

$\mathrm{m}=$ meridional

$\mathrm{rtr}=$ rotor

str $=$ stator

\section{Acknowledgment}

This research has been funded by the Swedish Energy Agency, Siemens Industrial Turbomechinery AB, Volvo Aero Corporation, and the Royal Institute of Technology through the Swedish research program TURBOPOWER. The support of which is gratefully acknowledged.

\section{References}

[1] European Communities, 2007, EU Action Against Climate Change: Leading Global Action to 2020 and Beyond, European Communities, Luxembourg.

[2] Metz, B., Davidson, O., Coninck, H. d., Loos, M., and Meyer, L., 2005, IPCC Special Report on Carbon Dioxide Capture and Storage, Cambridge University Press, New York.

[3] Brandels, L., 2006, "The ENCAP Project," http://www.encapco2.org

[4] Sanz, W., Jericha, H., Bauer, B., and Gottlich, E., 2008, "Qualitative and Quantitative Comparison of Two Promising Oxy-Fuel Power Cycles for CO2 Capture," ASME J. Eng. Gas Turbines Power, 130, p. 031702.

[5] Woollatt, G., and Franco, F., 2009, "Natural Gas Oxy-Fuel Cycles-Part 1 : Conceptual Aerodynamic Design of Turbo-Machinery Components," Proceedings of the 9th International Conference on Greenhouse Gas Control Technologies (GHGT-9), Washington, DC, November 16-20, pp. 573-580.

[6] Bolland, O., Kvamsdal, H., and Boden, J., 2005, "A Comparison of the Efficiencies of the Oxy-Fuel Power Cycles Water-Cycle, GRAZ-Cycle and Matiant-Cycle," Carbon Dioxide Capture for Storage in Deep Geologic Formations-Results from the CO2 Capture Project, Capture and Separation of Carbon Dioxide from Combustion Sources, Vol. 1, D. C. Thomas, ed., Advanced Resources International Inc., Arlington, VA, pp. 499-511.

[7] Bolland, O., and Mathieu, P., 1998, "Comparison of Two $\mathrm{CO}_{2}$ Removal Options in Combined Cycle Power Plants," Energy Convers. Manage., 39, pp. $1653-1663$.

[8] Sammak, M., Jonshagen, K., Thern, M., Genrup, M., Thorbergsson, E., Grönstedt, T., and Dahlquist, A., 2011, "Conceptual Design of A Mid-Sized SemiClosed Oxy-Fuel Combustion Combined Cycle," ASME Turbo Expo: Turbine Technical Conference and Exposition (GT2011), Vancouver, Canada, June 6-10, ASME Paper No. GT2011-46299.

[9] Ulizar, I., and Pilidis, P., 2000, "Handling of a Semiclosed Cycle Gas Turbine With a Carbon Dioxide-Argon Working Fluid," ASME J. Eng. Gas Turbines Power, 122, pp. 437-441.

[10] IPSEpro, 2003, "SimTech Simulation Technology (SimTech)," SimTech, Inc., Graz, Austria.

[11] National Institute of Standard and Technology, 2010, REFPROP, "Standard Reference Data Code."

[12] Ainley, D. G., and Mathieson, G. C. R., 1951, "A Method of Performance Estimation for Axial- Flow Turbines," Report No. ADA950664.

[13] Moustapha, H., Zelesky, M. F., Baines, N. C., and Japikse, D., 2003, Axial and Radial Turbines, Concepts NREC, White River Junction, VT.

[14] Benner, M., Sjolander, S. A., and Moustapha, S. H., 2006, "An Empirical Prediction Method for Secondary Losses in Turbines-Part I: A New Loss Breakdown Scheme and Penetration Depth Correlation," ASME J. Turbomach., 128(2), pp. 273-280.

[15] Benner, M. W., Sjolander, S. A., and Moustapha, S. H., 1995, "Influence of Leading-Edge Geometry on Profile Losses in Turbines at Off-Design Incidence: Experimental Results and an Improved Correlation," Proceedings of the International Gas Turbine and Aeroengine Congress and Exhibition, Houston, TX, June 5-8.

[16] Hartsel, J. E., 1972, "Prediction of Effects of Mass Transfer Cooling on the Blade Row Efficiency of Turbine Airfoils," Proceedings of the AIAA 10th Aerospace Science Meeting, San Diego, CA, January 17-19, AIAA Paper No. 72-11.

[17] Wright, P., and Miller, D., 1992, "An Improved Compressor Performance Prediction Model,” Report No. RR-PNR-90873. 
[18] Schwenk, F., Lewis, G., and Hartmann, M., 1975, "A Preliminary Analysis of the Magnitude of Shock Losses in Transonic Compressors," Report No. NASA RM E57A30.

[19] Allam, R., White, V., Ivens, N., and Simmonds, M., 2005, "The Oxyfuel Baseline: Revamping Heaters and Boilers to Oxyfiring by Cryogenic Air Separation and Flue Gas Recycle," Carbon Dioxide Capture for Storage in Deep Geologic Formations-Results from the CO ${ }^{2}$ Capture Project: Capture and Separation of Carbon Dioxide from Combustion Sources, Vol. 1, D. C. Thomas, ed., Advanced Resources International Inc., Arlington, VA, pp. 451-475.

[20] Darde, A., Prabhakar, R., Tranier, J.-P., and Perrin, N., 2009, “Air Separation and Flue Gas Compression and Purification Units for Oxy-Coal Combustion Systems," Proceedings of the 9th International Conference on Greenhouse Gas Control Technologies (GHGT9), Washington, DC, Novemer 16-20, pp. $527-534$.

[21] Amann, J. M., Kanniche, M., and Bouallou, C., 2009, "Natural Gas Combined Cycle Power Plant Modified into an $\mathrm{O}_{2} / \mathrm{CO}_{2}$ Cycle for $\mathrm{CO}_{2}$ Capture," Energy Convers. Manage., 50, pp. 510-521.

[22] Walsh, P., and Fletcher, P., 2004, Gas Turbine Performance, Blackwell Science, Inc., Oxford, UK.

[23] Horlock, J., 1966, Axial Flow Turbines: Fluid Mechanics and Thermodynamics, RE Krieger Pub. Co., Malabar, FL.
[24] Wennerstrom, A., 1990, "Highly Loaded Axial Flow Compressors: History and Current Developments," ASME J. Turbomach., 112, pp. 567-579.

[25] Dixon, S. L., 2005, Fluid Mechanics, Thermodynamics of Turbomachinery, Butterworth-Heinemann, Oxford, UK.

[26] Mukherji, D., and Rösler, J., 2011, "Design Considerations and Strengthening Mechanisms in Developing Co-Re-Based Alloys for Applications at $+100^{\circ} \mathrm{C}$ Above Ni-Superalloys," Adv. Mater. Res., 278, pp. 539-544.

[27] Walston, S., Cetel, A., MacKay, R., O'Hara, K., Duhl, D., and Dreshfield, R., "Joint Development of a Fourth Generation Single Crystal Superalloy," Report No. NASA/TM-2004-213062.

[28] Barry, B., 1976, "The Aerodynamic Penalties Associated With Turbine Blade Cooling," Rolls Royce plc, Derby, UK.

[29] Holland, M. J., and Thake, T. F., 1980, "Rotor Blade Cooling in High Pressure Turbines," J. Aircr., 17, pp. 412-418.

[30] Jonsson, M., and Bolland, O., 2005, "Gas Turbine Cooling Model for Evaluation of Novel Cycles," Proceedings of ECOS: 18th International Conference on Efficiency, Cost, Optimization, Simulation and Environmental Impact of Energy Systems, Trondheim, Norway, June 20-22.

[31] Corchero, G., Timon, V. P., and Montanes, J. L., 2011, "A Natural Gas OxyFuel Semiclosed Combined Cycle for Zero $\mathrm{CO}_{2}$ Emissions: A Thermodynamic Optimization,” Proc. Inst. Mech. Eng., Part A, 225, pp. 377-388. 